\title{
RELATION BETWEEN SEED APPEARANCE AND PHENOLIC MATURITY: A CASE STUDY USING GRAPES cv. CARMÉNÈRE
}

\author{
Claudio Fredes ${ }^{1 *}$, Eduardo Von Bennewitz ${ }^{1}$, Eduardo Holzapfel ${ }^{2}$, and Felipe Saavedra ${ }^{1}$
}

\begin{abstract}
Sensory evaluation of grapes (Vitis vinifera L.) plays a key role in determining the harvest time in grapevine varieties. The harvest time of cv. Carménère is one of the latest of Chile. During the season 2007-2008, the evolution of the appearance of Carménère seeds was evaluated as a harvest criterion, comparing it with the chemical and phenolic ripening. The samples were obtained from an organic vineyard located in Curicó Valley, Chile. Starting at $16{ }^{\circ}$ Brix, 100 seed berries samples were collected weekly from medium vigor vines in order to register photographically the ventral and dorsal sides of each seed. In addition to the seed tannins percentage, the extractable anthocyanins, total anthocyanins and total polyphenols index, as well as the titratable acidity, soluble solids and $\mathrm{pH}$ were registered. A color wheel of seed coat with a description of 12 digital colors was proposed for this cultivar. When the color number exceeded 10 (very dark brown), the soluble solids had already reached $24{ }^{\circ}$ Brix 1 month earlier. Two inverse correlations between seed coat color vs. seed phenols percentage and vs. total polyphenol index were found. The proper phenolic maturation (maximum anthocyanins and minimum seed tannins percentage) occurred $177 \mathrm{~d}$ post flowering. The observation of seed coat color can be a reliable, simple and low-cost parameter to determine the correct ripeness of phenols in 'Carménère' grapevines.
\end{abstract}

Key words: seed development, harvest index, seed color, phenols, Vitis vinifera.

\section{INTRODUCTION}

'Carménère' grapevine (Vitis vinifera $\mathrm{L}$.) is often harvested close to May (approximately 160-180 d post flowering), because it requires high accumulation of temperatures and luminosity for achieving low levels of seed phenols and methoxypyrazines in grapes (Gil and Pszczolkowski, 2007). The grapes picked early have a high concentration of 2-methoxy-3-isobutyl pyrazine (MIBP), a compound that gives an herbaceous aroma to the wine (Belancic and Agosin, 2007). Also, the high levels of tannin monomers present in the seed (Mattivi et al., 2009) require more time for minimizing the perception of astringency. For these reasons, this variety is not recommended for cool climates because of the herbaceous aroma and excessive astringency of the wines produced.

\footnotetext{
${ }^{1}$ Universidad Católica del Maule, Facultad de Ciencias Agrarias y Forestales, Casilla 7-D, Curicó, Chile. *Corresponding author (cfredes@ucm.cl).

${ }^{2}$ Viña Los Huañiles, Carmen 752, of. 404, Curicó, Chile. Received: 22 April 2009.

Accepted: 04 September 2009.
}

Phenolic compounds, located in the seed coats, include catechin, epicatechin and epicatechin gallate and seed tannins or procyanidins which are polymers of flavan-3-ol terminal extension subunits (Thorngate and Singleton, 1994). 'Carménère' seeds have a very high level of epicatechin gallate terminal units (Mattivi et al., 2009). Considering that the presence of epigallocatechin units in the proanthocyanidin tended to lower the "coarse" perception (Vidal et al., 2003), for improving grape quality it is necessary to carry out further studies about this monomer in this variety.

Changes in seed development are highly reflected in the sensory attributes of grapes. In aromas, MIBP has been found in grape skin (first) and seed (second) rather than in the pulp, both in 'Cabernet Sauvignon' and 'Chardonnay' (Hashizume and Samuta, 1997). The effects of seed tannins on wine flavor are well known. The new winemaking techniques of removing the seed during fermentation enable decreasing the extra tannins that are not always necessary (Antonini, 2007). Wine astringency is directly related with its tannin content (Smith et al., 2007), nevertheless the perception of astringency in wine can be influenced by other wine components (Kennedy, 
2008) and by the degree of degree of galloylation and polymerization of tannins (Vidal et al., 2003).

The polymerization degree of tannins (mPD), defined as the number of monomer units incorporated into the polymer, decreases with ripening (Kennedy et al., 2000) in all parts of the grape berry (Ó-Marques et al., 2005). The high reactivity of grape seed tannins is due to a lower degree of polymerization ( 3 to 4 ) and a higher degree of galloylation as compared with grape berry skin. Kennedy et al. (2000) point out that the mDP of tannin extracted from seed is typically 5 to 8 subunit. It is generally considered that flavan-3-ol monomers (catechin, epicatechin and epicatechin 3-O-galate) are bitterer than oligomers and polymers tannins, but proanthocyanidin chain length did not affect bitterness perception, irrespective of the proanthocyanidin classes (Vidal et al., 2003). Overall, the decrease in the bitterness perception is based upon the reduction in the lowest molecular weight tannins observed during berry ripening. This may provide a structural explanation for why tannin quality improves with fruit ripening (Kennedy, 2008). Saint Cricq et al. (1998) argue that the extractability of tannins decreases with fruit ripening, hence at harvest time, the amount of tannins must be at a minimum.

According to Thorngate and Singleton (1994) and Adams and Scholz (2007) the condensed tannins of the grape berries are polyphenolic compounds are formed prior to veraison in the hypodermal cells of the skin and the soft parenchyma cells of the seed. Adams and Scholz (2007) estimated that $60 \%$ of the wine tannin came from the seeds while only $40 \%$ came from the skins.

According Ristic and Iland (2005), seed maturity is related to the maximum dry weight and minimum extractable tannins of seed. A ripe berry is characterized by skins rich in anthocyanins and complex, relatively inactive tannins and seed with a low content of polymerized tannins that react strongly with proteins. Phenolic maturity explains the quantity and quality of phenols and the capacity to be extracted during vinification (Ribéreau-Gayon et al., 2000). Therefore, the anthocyanin extractability, assessed by the Glories method to determine harvest time depends on the ripening stage of the berry (Saint Cricq et al., 1998).

Ribéreau-Gayon et al. (2000) emphasize the strong relation between harvest time and the phenolic quality of wine-grapes. However phenolic determination is expensive and sophisticated for small farmers. These grape growers need fast, low-cost, simple and practical harvest indexes that can predict phenolic maturity defined as a moment when seeds tannins and skin anthocyanins concentration are minimum and maximum, respectively. Harvest time of red late varieties is often determined by enologists through sensorial evaluation. The color and taste of seeds are harvest criteria widely used by winemakers. They prefer the lowest presence of seed tannins, the darkest seed color and the easiness of pulp separation from the seed.

The color changes in seeds are related to polyphenol oxidation and are important from both an enological (Ristic and Iland, 2005) and ecological (Werker, 1980) point of view. The enologists highlight that these changes lead to a decline in their extractability and to an improvement in their astringency. Biologists highlight that seed changes result in seed dormancy, longevity and impermeability (Merbach and Mayer, 1975 cited by Kennedy et al., 2000).

The external appearance of seed coats may be used as an additional indicator of the overall berry ripeness (Ristic and Iland, 2005). These authors developed a gradual seed coat color chart for 'Shiraz', but it is not necessary valid for late varieties such as 'Carménère'. Also, there are differences between 'Syrah' and 'Carménère'. While the first is early ripening, the second ripens (Mattivi et al., 2009), and the presence of epicatechin gallate in seed of Syrah is $1.5 \%$, in 'Carménère' is $34.4 \%$. Overall, there is a strong relation between seed coat color and extractable tannins (Ristic and Iland, 2005). The aims of this research were to develop a simple and objective berry ripening index based on seed color and to compare the evolution of form and color of seed with the phenolic maturation and berry ripening in 'Carménère'grapevines. The technical application for this study was to predict phenolic maturity.

\section{MATERIALS AND METHODS}

The study was carried out in the Curicó Valley (34⒌' S, $\left.71^{\circ} 11^{\prime} \mathrm{W}\right)$ where there are average 1658 degree days ( $>10$ ${ }^{\circ} \mathrm{C}$ ) during the growing season. During the 2007-2008 season in self-rooted 'Carménère' vines, planted in 1997 and trained to a 4-cane vertical trellis. Plant spacing was $1.0 \mathrm{~m}$ in the rows and $2.0 \mathrm{~m}$ between rows. Yield has been approximately $10 \mathrm{t} \mathrm{ha}^{-1}$ annually. Shoot removal before flowering, partial leaf removal at veraison and total leaf removal at $21^{\circ}$ Brix were done on the vines. The vineyard was certified organic by BCS (Öko-Garantie GmbH, Nuremberg, Germany) in 2003. There were no Botritys, mold or powdery mildew infection of the experimental vines.

There were 70 homogeneous vines where grapes were picked. These selected vines were middle vigor vines that presented between 0.3 and $0.6 \mathrm{~kg} \mathrm{~m}^{-1}$ pruning weight per vine. Berries were randomly collected at $7 \mathrm{~d}$ intervals, starting on 14 February 2008, when berries had $16^{\circ}$ Brix and finished on 2 June 2008. Berry samples were analyzed the same day in Science Laboratory of Universidad Católica del Maule, Curicó. 
On each sampling date, berries were collected in a random manner from any cluster and vine already selected and then each grape was separated from the pulp and photographed in both surfaces (ventral and dorsal) for determination and assignation of color number. The ventral and dorsal surfaces were registered between 19:00 and 20:00 h by means of digital photos, obtained with natural light, always in the same place. The number of photos for each sampling date was 200 (100 for ventral side and 100 for dorsal side). A specific color wheel of seed color was developed based on Ristic and Iland (2005) seed coat color chart, but modified in their colors, according to the real color change of 'Carménère' seeds during ripening. This adaptation was elaborated with all digital photos obtained from ventral and dorsal seeds images, during ripening. These color scale had 12 digital colors developed with the system "red, green, blue with hue, saturation and brightness" (RGB-HSB). This is an electronic description of red, green and blue colors (RGB regulator) in terms of their hue, saturation, and brightness (HSB regulator). Hue values range from 0 to 360 (degrees), while saturation and brightness values range from 0 to $100(\%)$ (Comcast Interactive Media, 2009). The colors can be reproduced on any image editor computer (Table 1).

Seeds were compared in their dorsal and ventral surfaces with the color wheel for seed coat (Figure 1). The overall seed coat color was obtained calculating the average between the ventral and dorsal surfaces. The real and relative seed coat color (percentage with respect to color 11 or dark brown coloration) was determined based on Ristic and Iland (2005) methodology.

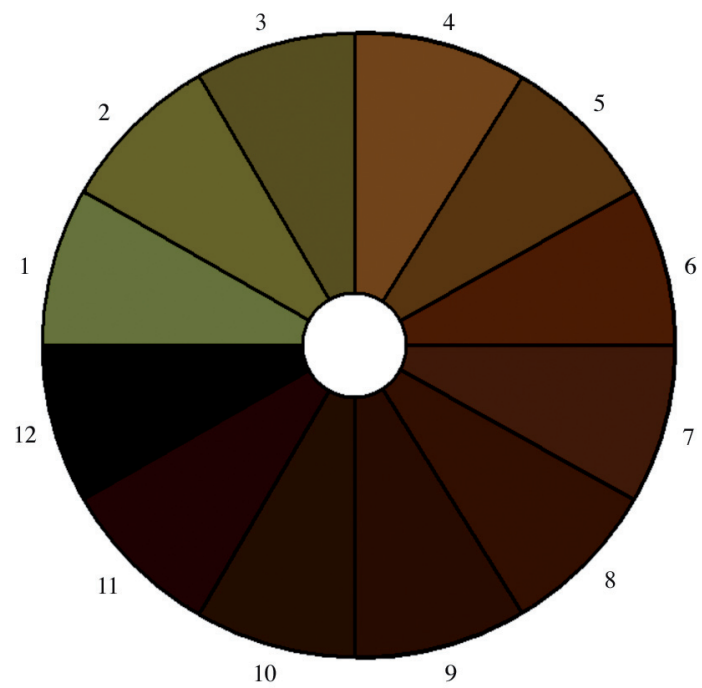

Figure 1. Color wheel of seed coat of Vitis vinifera $\mathrm{cv}$. Carménère.

Phenolic maturity was determined during ripening using the Glories method (Saint Cricq et al., 1998), which is based on the determination of seed tannins $(\%)$, extractability of anthocyanins $\left(\mathrm{mg} \mathrm{L}^{-1}\right)$ and total anthocyanins $\left(\mathrm{mg} \mathrm{L}^{-1}\right)$. The method of total polyphenol index, developed by the Institute for Viticulture and Oenology (ITV France), was applied for quantification of total polyphenols in grapes $\left(\mathrm{mg} \mathrm{kg}^{-1}\right.$ grape) (Lamadon, 1995). Analyses of $\mathrm{pH}$, titratable acid, expressed as tartaric acid, and soluble solids were determined by standard methods. The pulp composition was compared

Table 1. RGB and $\mathrm{HSB}^{1}$ values for 12 seed coat color defined for 'Carménère' grape ripening.

\begin{tabular}{|c|c|c|c|c|c|c|}
\hline \multirow[b]{2}{*}{ Seed coat color } & \multicolumn{3}{|c|}{ Regulator RGB ${ }^{1}$} & \multicolumn{3}{|c|}{ Regulator HSB ${ }^{1}$} \\
\hline & $\operatorname{Red}(\mathbf{R})$ & Green $(\mathbf{G})$ & Blue (B) & Hue (H) & Saturation & Brightness \\
\hline & & $-\%$ & 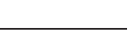 & Degree $\left({ }^{\circ}\right)$ & 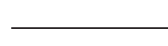 & 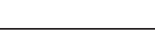 \\
\hline 1 & 116 & 106 & 56 & 70 & 52 & 45 \\
\hline 2 & 107 & 100 & 30 & 55 & 72 & 42 \\
\hline 3 & 94 & 83 & 37 & 48 & 61 & 37 \\
\hline 4 & 120 & 70 & 9 & 33 & 93 & 47 \\
\hline 5 & 94 & 57 & 28 & 26 & 70 & 37 \\
\hline 6 & 85 & 37 & 15 & 19 & 82 & 33 \\
\hline 7 & 71 & 39 & 28 & 15 & 61 & 28 \\
\hline 8 & 62 & 30 & 9 & 24 & 85 & 24 \\
\hline 9 & 56 & 30 & 13 & 24 & 77 & 22 \\
\hline 10 & 50 & 32 & 20 & 24 & 60 & 20 \\
\hline 11 & 47 & 18 & 22 & 352 & 62 & 18 \\
\hline 12 & 12 & 12 & 12 & 0 & 0 & 5 \\
\hline
\end{tabular}

Each seed coat color number represents a characteristic color of 'Carménère' seeds during ripening.

${ }^{1}$ Electronic description of red, green and blue colors (RGB regulator) in term of their hue, saturation, and brightness (HSB regulator). 
with seed coat color weekly since $16^{\circ}$ Brix. The phenolic maturity was biweekly determined since $17^{\circ}$ Brix.

The seed coat color corresponds to the average of 200 digital images in each sampling date (100 ventral plus 100 dorsal sides); the grape chemical composition corresponds to average in each sampling date. Correlations between measured variables were analyzed by simple linear regression. Statistical analyses were performed using SPSS software version 17. Graphics were done in MS Excel, using the means determined in each sampling date.

The dates of phenological stages of 'Carménère'grapevines and the days after bud breaking during 2007-2008 season in the Central Valley of Chile are shown in Table 2.

\section{RESULTS AND DISCUSSION}

Maximum soluble solids (24-25 ${ }^{\circ}$ Brix $)$ were attained on 7 April $142 \mathrm{~d}$ after flowering (DAF). Thereafter and until 7 May, there were no changes of soluble solids content (Figure 2). Conversano et al. (2008) argue that the highest quality scores were given to the fruit and the resulting wines harvested between 24 and $26{ }^{\circ}$ Brix in Napa Valley.

Color $\mathrm{N}^{\mathrm{o}} 10$ (very dark brown) of the seed coat color chart is normally recommended to start harvest. This color appeared $163 \mathrm{DAF}$; despite of the fact that a pulp sugar content of $24{ }^{\circ}$ Brix was attained $21 \mathrm{~d}$ before, at 142 DAF.

Table 2. Date of phenological stages in Vitis vinifera cv. Carménère during 2007-2008 season.

\begin{tabular}{lcccl}
\hline $\begin{array}{l}\text { Phenological stages of } \\
\text { Eichhorn and Lorenz }\end{array}$ & $\begin{array}{c}\text { Date (South } \\
\text { Hemisphere) }\end{array}$ & $\begin{array}{c}\text { Days after } \\
\text { flowering }\end{array}$ & $\begin{array}{c}\text { Days after } \\
\text { bud break }\end{array}$ & \multicolumn{1}{c}{$\begin{array}{c}\text { Description of } \\
\text { phenological stage }\end{array}$} \\
\hline 04 & 25 September & & 0 & Bud breaking \\
07 & 10 October & & 15 & First leaf unfolded \\
12 & 18 October & & 23 & Inflorescence clearly visible \\
17 & 2 November & & 38 & Single flowers separated \\
23 & 17 November & 0 & 53 & Full bloom \\
27 & 1 December & 14 & 67 & Fruit set \\
32 & 7 January & 51 & 104 & Bunch closure \\
34 & 18 January & 62 & 115 & Beginning of veraison \\
35 & 4 February & 79 & 132 & End of veraison \\
$38-39$ & 6 May & 171 & 224 & Commercial harvest ${ }^{2}$ \\
39 & 12 May & 177 & 230 & Recommended harvest ${ }^{3}$ \\
\hline
\end{tabular}

${ }^{1}$ Phenological stages proposed by Eichhorn and Lorenz and modified by Coombe (1995).

${ }^{2}$ Time chosen by the enologist.

${ }^{3}$ Time suggested by this study.

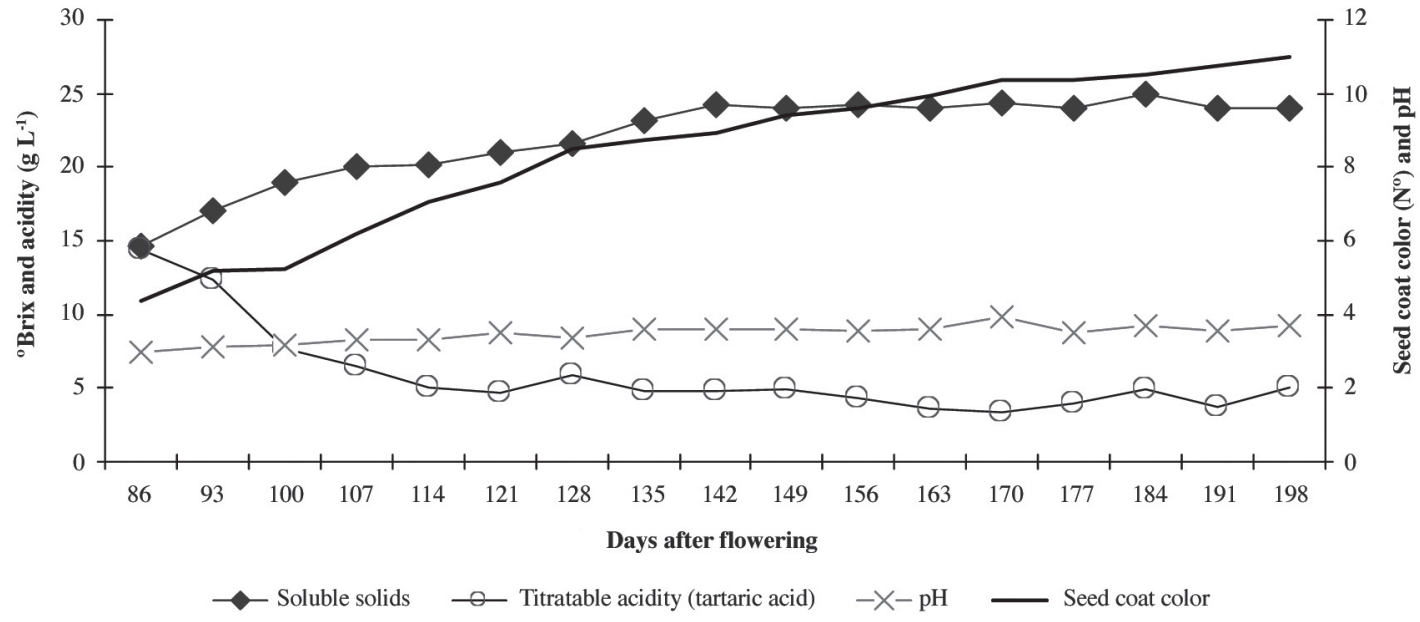

Each point represents the average of three replicates. The line of seed coat color was developed linking the average color of 100 seeds each $7 \mathrm{~d}$.

Figure 2. Evolution of soluble solids, acidity, $\mathrm{pH}$ and seed coat color in 'Carménère' grapes. 


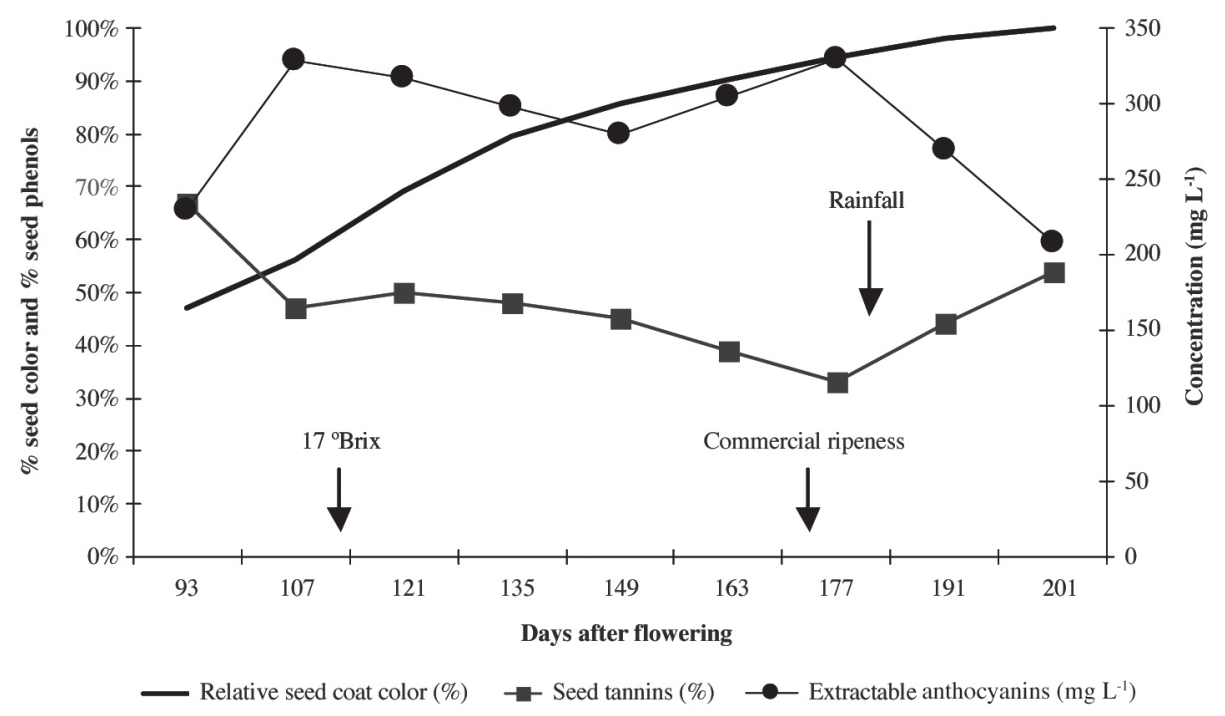

The line of seed coat color was developed linking the average color of 100 seeds each $7 \mathrm{~d}$.

Figure 3. Evolution of extractable anthocyanins, seed tannins percentage and relative seed coat color during fruit ripening of Vitis vinifera cv. Carménère.

The development of phenolic maturation in the late stage of ripening, with seed tannin percentage in declination and a notorious anthocyanins pick near the harvest (Figure 3), has also been described by Saint-Cricq et al., 1998; Ribéreau-Gayon et al., 2000; Ó-Marques et al., 2005, as well as the variations of seed coat color (Kennedy et al., 2000; Ristic and Iland, 2005). After berries attained $15{ }^{\circ}$ Brix, seed color changed from $\mathrm{N}^{\circ}$ 4 at veraison to $\mathrm{N}^{\circ} 11$ at harvest (Figure 1). Changes in seed coat color are related to changes in the phenolic composition of both seed and skin (Ristic and Iland, 2005) due to oxidation of phenols (Kennedy et al., 2000). Our work complements these two criteria for predicting harvest time of 'Carménère'. Starting at 93 DAF, when berries had $17^{\circ}$ Brix, until phenolic maturity at 177 DAF an inverse correlation $\left(R^{2}=0.76\right)$ was found between seed coat color and seed tannins percentage.

Ribéreau-Gayon et al. (2000) point out that the harvest should start when anthocyanins have reached their maximum concentration. In our experiment, the lowest levels of seed tannins (33\%), highest levels of extractable anthocyanins (330 $\left.\mathrm{mg} \mathrm{L}^{-1}\right)$ and total anthocyanins (793$1007 \mathrm{mg} \mathrm{L}^{-1}$ ) occurred at 177 DAF (12 May), when total and relative seed coat color were 10.38 and $94.36 \%$ respectively. Thereafter, anthocyanins concentration (total and extractable) decline and the level of seed tannins rose, probably due to a rainfall in 15 May or to excessive maturity. Kennedy et al. (2000) and Ribéreau-Gayon et al. (2000) argue that the anthocyanins content declines at late stages of berry development.
Neither soluble solids nor seed form were reliable ripening indexes, because a good sugar content (142 DAF: $24.2{ }^{\circ}$ Brix) and the final seed form (120 DAF: 21 ${ }^{\circ}$ Brix) were attained earlier than the phenolic maturity in our study. In 'Shyraz', neither seed form nor seed color had significant changes between 106-120 d after flowering (Ristic and Iland, 2005). Figure 4 shows developmental changes in the appearance of 'Carménère' seed. Approximately $107 \mathrm{DAF}$, seeds were fully formed with chalaza (top circle on dorsal side), raphe (line from top to bottom on the ventral side) and beak completely formed. Thereafter, as Ristic and Iland (2005) reported, seed continue their darkening and hardening. Kennedy et al. (2000) suggest that seed coat color changes coincide with a decreased in the rate of flavan-3-ol monomer biosynthesis and a rapid increase in polyphenols generation. In our study, during fruit ripening, changes in seed coat color was relatively constant but, in the last stages, between 163 and 198 DAF, there was only a 2\% weekly increment in seed coat color change (Figure 4).

Kennedy et al. (2000) proposed a last stage of fruit ripening called "non-programmed oxidation" that begins after berry weight has reached a maximum $\left(21^{\circ} \mathrm{Brix}\right)$, and that is characterized by an accumulation of nonanthocyanin glucosides, complete seed desiccation and leveling in the phenolic extraction and composition (Coombe and McCarthy, 2000). Changes after this time can be due to the presence of residual radical in the seed, which produce the oxidation of polyphenols (Kennedy et al., 2000). 


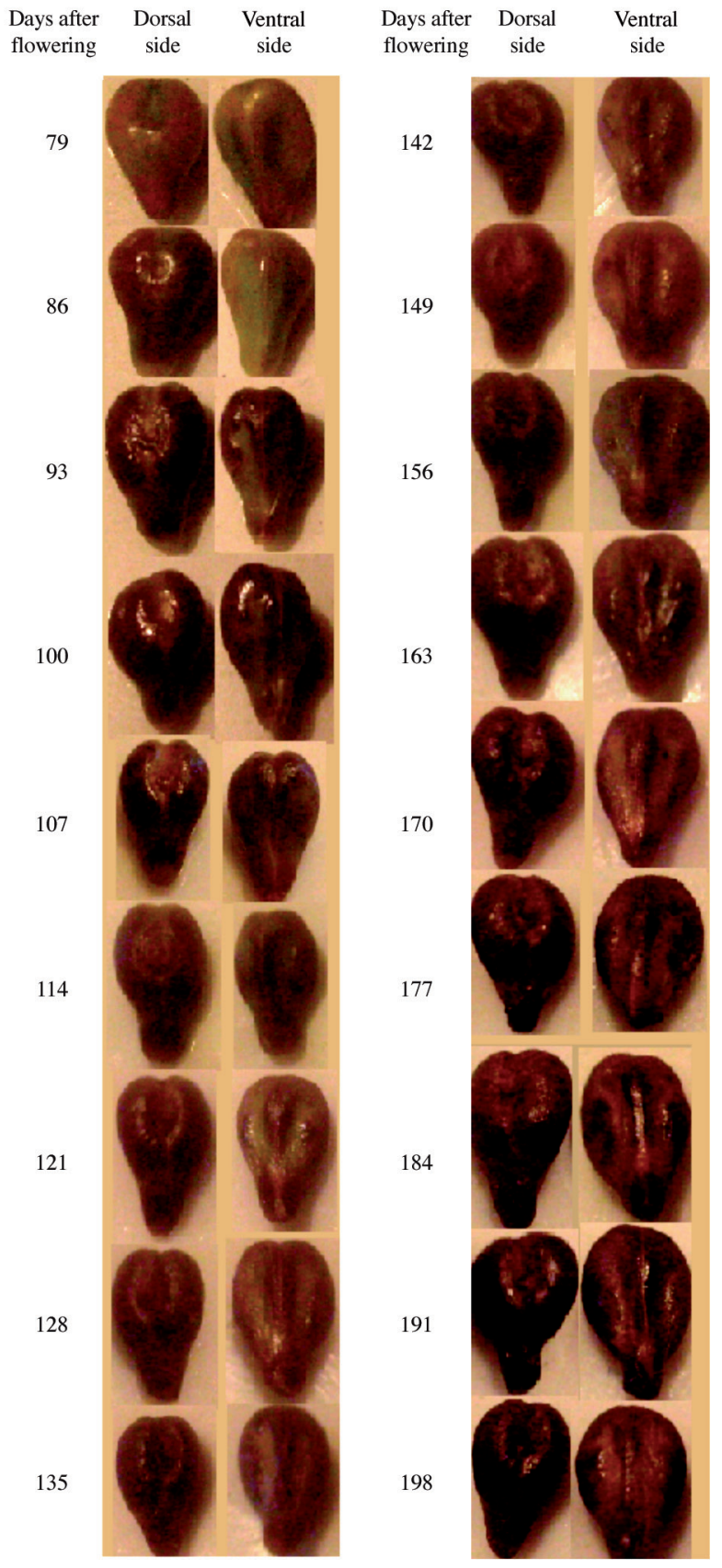

Figure 4. Linear diagram of developmental changes in the appearance of 'Carménère' grape seeds.

The evolution of total anthocyanins and phenols are showed in Figure 5. The anthocyanins had a pick at $20^{\circ}$ Brix (107 DAF) that was smaller than a second pick at $24.5^{\circ}$ Brix. At early ripening pick $\left(20^{\circ}\right.$ Brix $)$, the grapes reach the maximum grape weight (fresh and dry) and a rapid oxidation of seed tannins begins. Simultaneously the formation of beak, chalaza and raphe of seeds was completed, as reported by Ristic and Iland (2005). The last pick of total anthocyanins, at $177 \mathrm{DAF}$, was related to enological maturity (Ribéreau Gayon et al., 2000), coinciding with the maximum extractable anthocyanins and the minimum percentage of seed tannins.

Giovanelli and Brena (2007) and Ó-Marques et al. (2005) report that total phenols decrease with maturity. Consistently, the total polyphenol index decreased regularly during fruit ripening. The total polyphenol index (TPI) and seed coat color number were strongly related from $17^{\circ}$ Brix (93 DAF, 18 February) until winter dormancy (201 DAF, 2 June), showing an inverse correlation of $\mathrm{R}^{2}=0.96$ (Figure 6). Bautista (2005) also found a decline in TPI with fruit ripening.

The period between $20{ }^{\circ}$ Brix (107 DAF) and the recommend maturity in this study (177 DAF) was quite long. Further research is needed to investigate the seed coat anatomy as well as the seed monomers and tannins in order to describe the phenolic evolution of seeds and its extractability in 'Carménère' grapevines.

The date harvest proposed by using seed color and phenolic maturity implied to delay significantly harvest and it could cause two possible negative effects on grapes: 1) to decrease free amino $\mathrm{N}$ content become less available (Bordeu, 2000); and 2) to develop fungal disease. Pszczolkowski et al. (2001) studied mold on late harvested 'Cabernet Sauvignon' grapes in several vineyards of Chile (harvested between 25 April and 8 May) and concluded that yield and wine quality were reduced by grape mold (mainly Cladosporium herbarum and Alternaria alternata). It is important to consider that seed color index should not be used lately when the grape health can be affected. On the other hand, if the grape is health at this time, it would increase $\mathrm{N}$ levels for fermentation, when it will be necessary.

\section{CONCLUSIONS}

The phenolic maturity (minimum seed tannins, maximum anthocyanins) was determined $2 \mathrm{wk}$ after the seed coat color exceeded number 10 (very dark brown). At that moment the seed coat color number was 10.4.

Complementing maturity phenols (minimum seed tannins, maximum skin anthocyanins) and seed coat color as harvest criteria in Carménère grapes confirmed this as a very late variety, because the appropriate date for picking the berries occurred in early may (South Hemisphere) at $177 \mathrm{~d}$ after flowering.

The phenols were mature for harvesting, almost $1 \mathrm{mo}$ after the soluble solid had reached $24^{\circ}$ Brix and 2 mo after the seeds already had reached their definitive form. The seed color coat color presented a continual evolution until $100 \%$ of color $\mathrm{N}^{\circ} 11$ in winter dormancy, but the phenolic maturation occurred at a relative seed color of $94.4 \%$. 


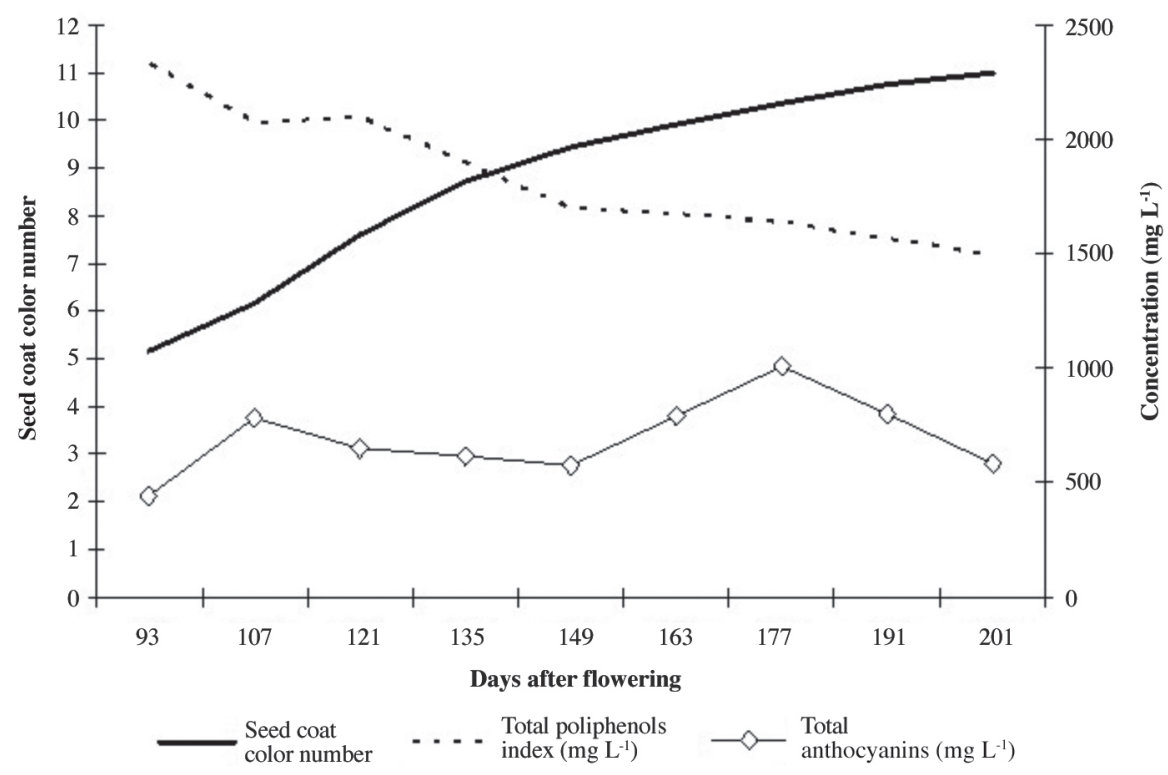

The line of seed coat color was developed linking the average color of 100 seeds each $7 \mathrm{~d}$.

Figure 5. Changes in total polyphenol index, total anthocyanins and seed coat color number during fruit ripening in 'Carménère' grapes.

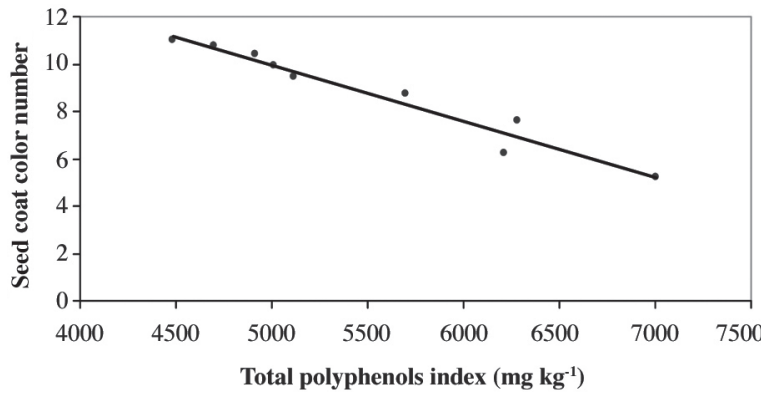

Figure 6. Relation between the seed coat color number and the total polyphenol index during ripening in 'Carménère' grapes $\left(\mathbf{R}^{2}=\mathbf{0 . 9 6}\right)$.

The seed coat color is a reliable and simple ripening index for determining the harvest date. This study made available the RGB and HSB values of the 12 colors observed during ripening for self-construction on any image editor computer.

\section{RESUMEN}

Relación entre apariencia de semillas y madurez fenólica: Un estudio de caso usando uvas cv. Carménère. La evaluación sensorial de uvas (Vitis vinifera L.) juega un rol clave en la determinación de la fecha de cosecha en los últimos estados de la maduración de la baya. La cosecha del cv. Carménère es una de las últimas en Chile.
Durante la temporada 2007-2008, la evolución de la apariencia de semillas 'Carménère' fue evaluada como un criterio de cosecha, comparándola con la madurez química y fenólica. Las muestras fueron obtenidas desde una viña orgánica localizada en el valle de Curicó, Chile. Se colectaron semanalmente 100 bayas desde vides de vigor medio con el fin de registrar fotográficamente las caras ventral y dorsal de cada semilla, comenzando las mediciones a los $16{ }^{\circ}$ Brix. Además del porcentaje de taninos de semilla, las antocianas extraíbles, antocianas totales y el índice de polifenoles totales, como también el $\mathrm{pH}$, acidez y los sólidos solubles fueron registrados. Una rueda de color de la cubierta de semilla con una descripción de 12 colores digitales fue propuesta para este cultivar. Cuando el color excedió el número 10 (café muy oscuro), los sólidos solubles habían alcanzado los $24^{\circ}$ Brix un mes antes. Dos correlaciones inversas entre el color de cubierta de semilla vs. porcentaje de taninos de semilla y vs. índice de polifenoles totales fueron encontradas. La madurez fenólica adecuada (máximo de antocianas y mínimo de taninos de semilla) ocurrió 177 días posfloración. La observación del color de cubierta de semilla puede ser un parámetro confiable, simple y económico para determinar la correcta madurez de fenoles en vides 'Carménère'.

Palabras clave: desarrollo seminal, índice de cosecha, color seminal, fenoles, Vitis vinifera. 


\section{LITERATURE CITED}

Adams, D.O., and R.C. Scholz. 2007. Tannins - the problem of extraction. p. 160-164. In Rae, B., P. Williams, and S. Pretorius (eds.) Conference Proceedings $13^{\text {th }}$ Australian Wine Industry Technical Conference, Adelaide, South Australia. 28 July-2 August 2007. Australian Wine Industry Conference, South Australia, Australia.

Antonini, A. 2007. Tension between 'Old World' winemaking practices and innovation. p. 125-127. In Rae, B., P. Williams, and S. Pretorius (eds.) Conference Proceedings $13^{\text {th }}$ Australian Wine Industry Technical Conference, Adelaide, South Australia. 28 July-2 August 2007. Australian Wine Industry Conference, South Australia, Australia.

Bautista, A. 2005. Técnicas enológicas para la obtención de vinos de monastrell de alto contenido polifenólico. 364 p. Tesis para obtener el grado de Doctor. Universidad de Murcia, Departamento de Tecnología de Alimentos, Nutrición y Bromatología, Murcia, España.

Belancic, A., and E. Agosin. 2007. Methoxypyrazines in grapes and wines of Vitis vinifera $\mathrm{cv}$. Carménère. American Journal of Enology and Viticulture 58:462469.

Bordeu, E. 2000. Niveles de nitrógeno fácilmente asimilable. Agronomía y Forestal UC (Chile) 3(10):47.

Comcast Interactive Media. 2009. Relationships between HSB and RGB color descriptions and the Java builtin colors. Available at http://home.comcast.net/ edabramson/14ColorTest/HSB-and-RGB-Colors.html (accessed March 2009).

Conversano, M., M. LiCalzi, K. Skogerson, M.A. Matthews, H. Heymann, and S.E. Ebeler. 2008. Role of fruit maturity on winemaker harvest decisions for Cabernet Sauvignon wines. p. 1. In Technical Abstract 59 $9^{\text {th }}$ Annual Meeting, Oregon, USA. 17-20 June 2008. American Society for Viticulture and Enology, Davis, California, USA.

Coombe, B. 1995. Adoption of a system for identifying grapevine growth stages. Australian Journal of Grape and Wine Research 1:100-110.

Coombe, B.G., and M.G. McCarthy. 2000. Dynamics of grape berry growth and physiology of ripening. Australian Journal of Grape and Wine Research 6:131-135.

Gil, G., and P. Pszczolkowski. 2007. Viticultura, fundamentos para optimizar producción y calidad. p. 535. Ediciones Universidad Católica de Chile, Santiago, Chile.
Giovanelli, G., and O. Brenna. 2007. Evolution of some phenolic components, carotenoids and chlorophylls during ripening of three Italian grape varieties. European Food Research and Technology 225:145150.

Hashizume, K., and T. Samuta. 1997. Green odorants of grape cluster stem and their ability to cause a wine stemmy flavor. Journal of Agricultural and Food Chemistry 45:1333-1337.

Kennedy, J. 2008. Grape and wine phenolics: Observations and recent findings. Ciencia e Investigación Agraria 35:107-120.

Kennedy, J., G.J. Troup, J.R. Pilbrow, D.R. Hutton, D. Hewitt, C.R. Hunter, et al. 2000. Development of seed polyphenols in berries from Vitis vinifera L. cv. Shiraz. Australian Journal of Grape and Wine Research 6:244-254.

Lamadon, F. 1995. Protocole pour I'évaluation de la richesse polyphénolique des raisins. Revue des Oenologues 76:37-38.

Mattivi, F., U. Vrhovsek, D. Masuero, and D. Trainotti. 2009. Differences in the amount and structure of extractable skin and seed tannins amongst red grape varieties. Australian Journal of Grape and Wine Research 15:27-35.

Ó-Marques, J., R. Reguinga, O. Laureano, e J. Ricardoda-Silva. 2005. Alterações ao longo da maturação nos taninos condensados da grainha, película e polpa: influência da monda de cachos. Ciência e Técnica Vitivinicola 20(1):35-52.

Pszczolkowski, Ph., B.A. Latorre, and C. Ceppi Di Lecco. 2001. Efectos de los mohos presentes en uvas cosechadas tardiamente sobre la calidad de los mostos y vinos Cabernet Sauvignon. Ciencia e Investigación Agraria 28(3):157-163.

Ribéreau-Gayon, P., Y. Glories, A. Maujean, and D. Dubourdieu. 2000. Handbook of enology. Vol. 2. The chemistry of wine stabilization and treatments. p. 441. $2^{\text {nd }}$ ed. John Wiley \& Sons, Chichester, England.

Ristic, R., and P. Iland. 2005. Relationships between seed and berry development of Vitis vinifera L. Cv. Shiraz: Developmental changes in seed morphology and phenolic composition. Australian Journal of Grape and Wine Research 11(1):43-58.

Saint-Cricq, N., N. Vivas, and Y. Glories. 1998. Maturation phénolique: définition et contrôle. Revue Française d'Enologie 173:22-25. 
Smith, P.A., M.D. Mercurio, R.G. Dambergs, I.L. Francis, and M.J. Herderich. 2007. Grape and wine tannin are there relationships between tannin concentration and variety, quality, and consumer preference? p. 189-192. In Rae, B., P. Williams, and S. Pretorius (eds.) Conference Proceedings 13th Australian Wine Industry Technical Conference, Adelaide, South Australia. 28 July-2 August 2007. Australian Wine Industry Conference, South Australia, Australia.

Thorngate, J.H., and V.L. Singleton. 1994. Localization of procyanidins in grape seeds. American Journal of Enology and Viticulture 45(2):259-262.
Vidal, S., L. Francis, S. Guyot, N. Marnet, M. Kwiatkowski, R. Gawel, et al. 2003. The mouth-feel properties of grape and apple proanthocyanidins in a wine-like medium. Journal of the Science of Food and Agriculture 83:564-573.

Werker, E. 1980. Seed dormancy as explained by the anatomy of embryo envelopes. Israel Journal of Botany 29:22-44. 